\title{
A Review on Land Use in the Malaysian State of Sarawak, Borneo and Recommendations for Wildlife Conservation Inside Production Forest Environment
}

\author{
JASON HON ${ }^{*} \&$ SHOZO SHIBATA \\ Laboratory of Landscape Ecology and Planning, Graduate School of Global Environmental Studies, \\ Kitasirakawa-oiwake-cho, Sakyo-ku, Kyoto, Japan 606-8502
}

\begin{abstract}
The Malaysian state of Sarawak, which lies in the island of Borneo, is rich in plant and animal diversity, and forms one of the global biodiversity hotspots. The major land uses include logging, agriculture and forest plantations. Deforestation and degradation of forests are occurring at a rate of $0.64 \%$ annually, largely due to expansion of oil palm plantations which increases at an average rate of $10.2 \%$ annually. More areas are being converted into forest plantations, which accounts for $3.25 \%$ of the total forested area. On the other hand, protected areas remain small, representing only $6.64 \%$ of total forested area or $4.23 \%$ of the total land area, and are located far apart. The bulk of forests are subjected to logging and many areas may be converted in the future to other land use such as agriculture. Furthermore, logging has been a major economic activity, and will continue to be so in the future. Hence, the network of production forests become crucial for wildlife and working with logging companies in this aspect is a realistic approach towards wildlife conservation. Some measures proposed include encouraging collaborative research in production forests; making sustainable forest management practices mandatory; creating buffer zones in areas adjacent to protected areas; and maintaining maximum connectivity of habitat for wildlife.
\end{abstract}

Keywords: Forestry, land use, Sarawak, wildlife conservation

\section{INTRODUCTION}

Tropical forest lies within the equatorial zone between the Tropics of Cancer and Tropics of Capricorn and has very high species abundance and species endemism than any other regions of the world (Myers, 1988). There are over 185,000 species of flowering plants (Prance, 1995), of which around 37,000 species are trees (Odegaard, 2000), with many more remained undescribed (Ghazoul \& Sheil, 2010). Within the tropical forest region, Southeast Asia forms one of the global biodiversity hotspots, home to $20-25 \%$ of the world's plant and animal species (Myers et al., 2000; Mittermeier et al., 2005, 2011; Woodruff, 2010). The Sundaland is one of the four bioregions in Southeast Asia, and contains over 25,000 species of plants including 15,000 endemics, and 1,800 vertebrate species of

*Corresponding author:jasonhonss@gmail.com which 701 are endemics (Brooks et al., 2002; Myers et al., 2000; Mittermeier et al., 2011). Within this bioregion is the island of Borneo, which has the richest tree diversity of between 10,000 to 15,000 species (Wikramanayake et al., 2001; MacKinnon et al., 1996). Borneo is the distribution centre for the Dipterocarpacea family, comprising 291 species or $75 \%$ of the family, and is a dominant and important commercial timber species in Southeast Asia (Soepadmo \& Wong, 1995; Ashton, 1982, 2004). The richness of a single tree family i.e. Dipterocarpacea, growing in one place is not matched by anywhere else in the world (Whitmore, 1988).

However, habitat destruction and over exploitation are threatening the biodiversity and subsequently the ecological services provided by them (Sodhi \& Brook, 2006). Land cover is changing at very fast rate, whereby natural ecosystems and forests are converted to other land uses such as large scale plantations and small-holder dominated farming areas (Koh \& Wilcove, 2008; Wilcove 
\& Koh, 2010); or became degraded due to fire and logging (Achard et al., 2002; Langner et al., 2007; Miettinen et al., 2011). Tropical forests in Southeast Asia experience the highest rate of loss and degradation, resulting in less than half its original forest cover remaining (Corlett \& Primack, 2008; Achard et al., 2002). In 2000, forest cover declined from $51 \%$ to $49 \%$, and is projected to reduce to $46 \%$ in 2020 (FAO, 2011). In Malaysia alone, forest cover decreased by $8.58 \%$ from 22.4 Mha in 1990 to $20.5 \mathrm{Mha}$ in 2010 , and is projected to decrease further to 20.0 Mha in 2020, largely due to pressures from conversion to agriculture coupled by the slowness in increasing coverage of permanent forest reserves (FAO, 2011). Logged over tropical forest have always been under tremendous pressure to be converted to other more profitable land use (Laurance, 2007), unless they are granted perpetual protection status. In cases where protected areas are already in place, most of them are underfunded and under protected (Corlett \& Primack, 2008). Sadly, many of the existing protected areas are fragmented and may not hold bright prospects as they are constantly encroached (Curran et al., 2004), and lack the manpower to manage them properly (Tisen \& Bennett, 2002).

This paper provides a review on the status of land use and changes in the Malaysian state of Sarawak, which is situated in Borneo, and examines the importance of forestry as one of the major economic activities. Arguments on land use and management policies especially pertaining to forestry and recommendations to address the conservation of wildlife, in tandem with sustainable development and forest management are discussed.

\section{MATERIALS \& METHODS}

\section{Study area}

The study area is the state of Sarawak, which lies between $0^{\circ} 50^{\prime}-5^{\circ} 0^{\prime} \mathrm{N}$ and $109^{\circ} 36^{\prime}$ $115^{\circ} 40^{\prime} \mathrm{E}$ in the island of Borneo, and forms part of the Federation of Malaysia. It covers an area of 12.32 Mha and has a population of 2.47 million. Sarawak experiences a hot and humid equatorial monsoon climate, with a mean annual rainfall of over $3,800 \mathrm{~mm}$ and daily temperature range of $22^{\circ} \mathrm{C}$ to $33^{\circ} \mathrm{C}$. The gross domestic production was RM83.8 billion and export was valued at RM76.2 billion in 2010, the bulk from petroleum and gas, followed by oil palm and timber products (DOS, 2011). The major types of lowland vegetation include peat swamp forest, mixed dipterocarp forests and heath forest.

\section{Statistical data and maps}

We conducted extensive literature reviews and sourced data from the Department of Statistics Malaysia, which publishes annual data on key statistics of Sarawak and keeps historical records of various publications from other government agencies (DOS, 2011). We reviewed both published and unpublished reports of relevant agencies (e.g. Forestry Department of Sarawak, Sarawak Forestry Corporation, Department of Agriculture), and digitised the map of protected areas of Sarawak (SFC, 2012). The base map for land use was sourced from Miettinen et al. (2012).

\section{RESULTS \& DISCUSSION}

\section{Forest cover and land use changes}

In 2010 , it was reported that the total forested area in Sarawak was 7.85 Mha or $63.76 \%$ of land area (DOS, 2011) and agricultural land was 1.35 Mha (10.96\%) (DOA, 2011). Historically, the first agricultural activity to have significant impact on forests of Sarawak was rubber (Hevea brasiliensis), which was introduced in 1881, followed by large scale planting in 1905 mostly in the form of smallholders (Aiken \& Leigh, 1992), a situation which remains until today (DOS, 2010). By 1964, rubber was replaced by timber as the main export when large scale logging begun in the late 1940s mostly along the coastal peat swamp forest (Aiken \& Leigh, 1992). Forestry intensified during the 1970s, when hill logging technology improved (Wong, 1992) and this accelerated the exploitation of interior forests (Aiken \& Leigh, 1992). The mixed dipterocarp forest, which contained large and tall standing species such as Dryobalanops lanceolata, Shorea superba and Dipterocarpus caudiferus, were the first to be logged and subsequently converted into agriculture (Ashton, 1995).

Forestry is governed by the Forest (Amendment) Ordinance which specifically spells out the requirement for a permit to remove forest produce (Government of Sarawak, 2001). The Forest Department of 
Sarawak (FDS) is entrusted with this obligation of overseeing the management of permanent forests, including national parks and wildlife sanctuaries (Government of Sarawak, 1998a; 1998b) and has control over land use especially regulating logging by issuing licenses or permits for such activities. There are three main categories of forests, supposedly to remain under forest cover in perpetuity and are classified as Permanent Forest (PF). PF consists of: (i) Forest Reserves (FR), which are generally production forests;

(ii) Protected Forests, which are constituted for the primary purposes of protection of soils and waters where intensive production of forest crops is unlikely to be practicable; and (iii) Communal Forests, which are areas used by the community concerned. The administrative term of Permanent Forest Estates (PFE) is used for PF. According to international definition, production forests are forested area designated for production and extraction of both wood and non-wood products (FAO, 2004).

In Sarawak, PF covers $57.71 \%$ of the forested area and are mostly dedicated to production forestry. The total area already licensed out for timber extraction is not known, with expert analyses and guesses putting the figure at about 8.8 Mha in the early $1990 \mathrm{~s}$ (GTZ, 1992). If this figure was taken to be accurate, the total area approximately matched the entire PF category, meaning to say that all available forests have already been licensed out and have been logged, are being logged and are potentially to be logged in the near future. Jomo et al. (2004) noted that over $90 \%$ of forest in Sarawak is available for logging, a figure which is almost the same as the total PF category. Only a small percentage of forested area, i.e. $6.64 \%$ has legal protection status as national parks, nature reserves or wildlife sanctuaries. On the other hand, State Land has more extensive coverage, with the least protection status, and can be potentially alienated and converted to other uses, including timber harvesting. In more recent years, forest plantations were established, and forms part of the permanent forests i.e. they are classified as PF (Government of Sarawak, 2001). As most of the species planted are nonnative, forest plantations may be constituted as 'farms' rather than 'forests'. If this definition is used, the total forested area in Sarawak may even be much lower than commonly reported.

The greatest impact from land conversion in Sarawak is oil palm (Elaeis guineensis), accelerated by the exhaustion of land bank in Peninsular Malaysia. Malaysia has been a top palm oil producing country since 1970 s, and together with Indonesia, account for more than $85 \%$ of the world's production (FAO, 2012a). Under the Third National Agriculture Policy (1998-2010), more land in Sarawak was designated for planting oil palm (MOA, 1998) and since then, an average annual increment of $10.5 \%$ in planted area was achieved since 2002, the highest for all states in Malaysia. Direct calculation based on yearly increment of oil palm planted area against the total land area, shows a minimum average annual conversion rate of $0.42 \%$ since 2002 (Table 1), largely converted from peat swamp forests (Tsuyuki et al., 2011). Deforestation in Sarawak, which occurred at an average rate of $0.64 \%$ per year, whereby intact inland forest experienced a loss of about 0.5 Mha within two decades since 1990, was mostly attributed to large scale expansion of oil palm plantations (Tsuyuki et al., 2011).

The loss of forest cover has also been attributed to shifting agriculture practices. Historically in Sarawak and prior to independence, conversion of forest to large scale agriculture plantations for economic development was never strongly advocated because of issues related with the complexity of native customary rights land and ownership of land; and the physical characteristics of the soil conditions both in the lowland and interior that did not favour agricultural development (Jomo et al., 2004). Instead, logging has been blamed for the rapid degradation of forests since large scale commercial forestry started in the 1960s (Aiken \& Leigh, 1992) of which in less than two decades from 1980, the loss was $12 \%$ (Jomo et al., 2004). By itself, shifting agriculture by natives is unlikely to have contributed to such large scale forest damage at such pace (Ichikawa, 2007). A study conducted in northern Sarawak in Lambir indicated that land use changes, especially native land, accelerated when accessibility by road increased, which in turn also affected the economy of the area that were created by demands generated from the expansion of 
Table 1. Oil palm planted areas in top producing states in Malaysia.

\begin{tabular}{|c|c|c|c|c|c|c|c|c|c|c|}
\hline \multirow{2}{*}{ Year } & \multicolumn{4}{|c|}{ Planted area (ha) } & \multicolumn{4}{|c|}{ Annual rate of increase (\%) } & \multicolumn{2}{|c|}{ Annual change in Sarawak } \\
\hline & Sarawak & Sabah & Johor & Pahang & Sarawak & Sabah & Johor & Pahang & $\begin{array}{l}\text { Area } \\
\text { (ha) }\end{array}$ & $\begin{array}{c}\text { Percentage of land } \\
(\%)\end{array}$ \\
\hline 2001 & 374,828 & $1,027,329$ & 636,782 & 532,500 & & & & & & \\
\hline 2002 & 414,260 & $1,068,973$ & 664,059 & 584,482 & 10.5 & 4.1 & 4.3 & 9.8 & 39,432 & 0.32 \\
\hline 2003 & 464,774 & $1,135,100$ & 659,639 & 583,276 & 12.2 & 6.2 & -0.7 & -0.2 & 50,514 & 0.41 \\
\hline 2004 & 508,309 & $1,165,412$ & 666,368 & 578,848 & 9.4 & 2.7 & 1.0 & -0.8 & 43,535 & 0.35 \\
\hline 2005 & 543,398 & $1,209,368$ & 667,872 & 606,821 & 6.9 & 3.8 & 0.2 & 4.8 & 35,089 & 0.28 \\
\hline 2006 & 591,471 & $1,239,497$ & 671,425 & 623,290 & 8.8 & 2.5 & 0.5 & 2.7 & 48,073 & 0.39 \\
\hline 2007 & 664,612 & $1,278,244$ & 670,641 & 641,451 & 12.4 & 3.1 & -0.1 & 2.9 & 73,141 & 0.59 \\
\hline 2008 & 744,372 & $1,333,567$ & 687,907 & 647,879 & 12.0 & 4.3 & 2.6 & 1.0 & 79,760 & 0.64 \\
\hline 2009 & N/A & N/A & N/A & N/A & 12.8 & - & - & - & \multirow{3}{*}{\multicolumn{2}{|c|}{$\begin{array}{l}\text { Average increase in oil palm } \\
\text { planted areas from } 2002 \text { to } \\
2008 \text { is } 0.42 \%\end{array}$}} \\
\hline 2010 & N/A & N/A & N/A & N/A & 9.5 & - & - & - & & \\
\hline 2011 & $1,021,587$ & $1,431,762$ & 721,145 & 694,801 & 11.0 & - & - & - & & \\
\hline
\end{tabular}

logging and plantation activities in the surrounding State Land (Ichikawa, 2007). Therefore, it could be implied that logging and plantation activities may have accelerated the expansion of shifting agriculture areas, the former occurring at faster pace in the lesser regulated government owned State Land, resulting in major land use changes.

\section{Economy of forestry}

Historical data showed that up to the late 1970 s, some $76 \%$ of Sarawak was under forest cover, of which $90 \%$ was under logging concession, but between 1963 and 1986, an estimated $30 \%$ or more of forest area was logged (Blaser et al., 2011). Log production picked up momentum in the late 1970s, climbing steadily and peaked in 1991 with over $19 \mathrm{Mm}^{3}$ harvested before it started to decline (Figure 1). The International Tropical Timber Organisation (ITTO) (1990) made the recommendation to limit production to 9.2 $\mathrm{Mm}^{3}$ in order to be sustainable in the long term, on conditions that silviculture treatments are applied with restrictions on logging in State Land and steep slopes. Economically, the timber industry contributed RM22.5 billion to
Malaysia's export and employed over 300,000 people in 2008 (Government of Malaysia, 2011), making the country one of the top exporter of tropical timber products in the world. In Sarawak alone, the number of workers employed in the timber industry such as sawmilling and wood processing, but not including logging, reached 193,011 in 2005 (Government of Malaysia, 2011). The role of Malaysia, and particularly Sarawak, in the global economy of tropical timber, is significant. In 2009, Sarawak collected RM 4.563 billion in forest revenues (DOS, 2011), of which the direct revenue from the collection of premia, royalties and tariffs amounted to RM 412 million or $9.03 \%$ of the total revenue (Table 2) (FDS, 2009).

\section{Expansion of forest plantations - a more recent activity}

In more recent time, forest plantations are expanding, resulting in significant land use changes in Sarawak. In 2008, the total forest plantation area in Sarawak was 207,502 ha, about a quarter of the total 863,296 ha throughout Malaysia (STA, 2012). By 2009, the total planted area in Sarawak increased by 


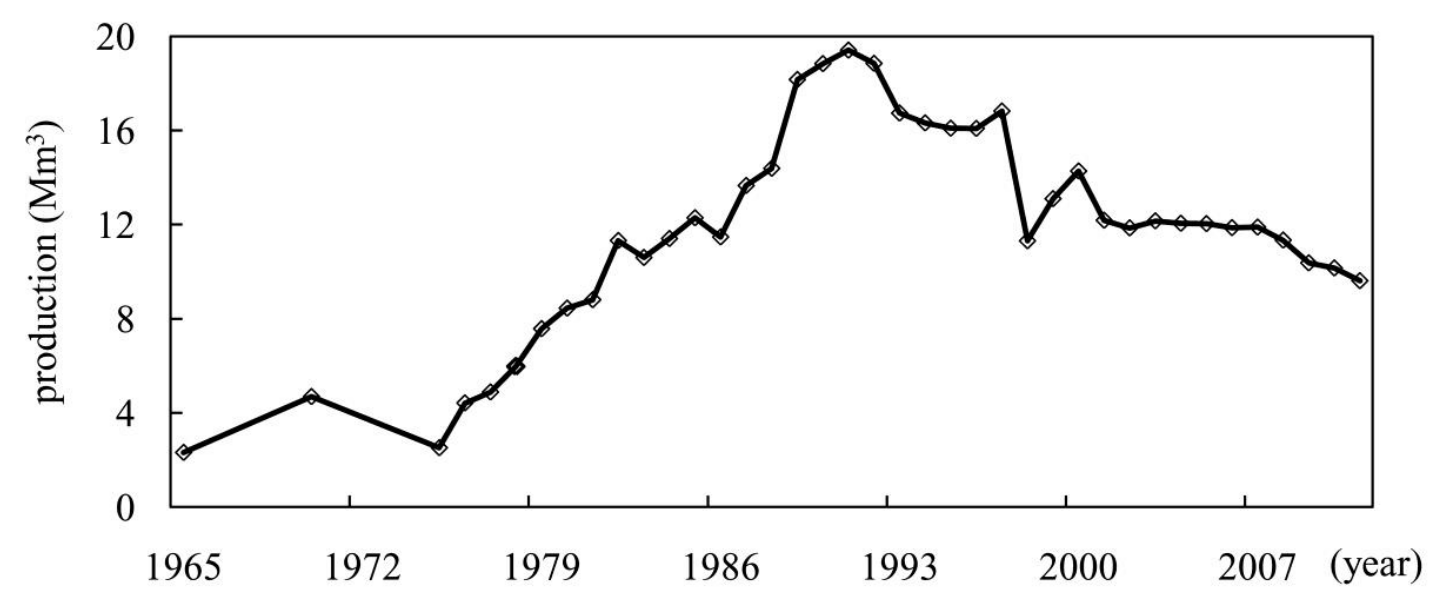

Figure 1. Production of logs from Sarawak since 1965, showing marked increase from the 1970s to 1990, before experiencing a constant decline after that.

Table 2. Revenues collected by Forest Department of Sarawak from forests related activities.

\begin{tabular}{lccc}
\hline \multicolumn{1}{c}{ Category } & Value (RM) & Percentage (\%) & $\begin{array}{c}\text { Percentage of state's } \\
\text { revenue (\%) \# }\end{array}$ \\
\hline Premia, royalties, tariffs & $411,974,677.32$ & 95.5 & 9.03 \\
Licence and permits & $13,257,275.00$ & 3.1 & 0.29 \\
National Park fees & $2,658,532.00$ & 0.6 & 0.06 \\
Others, including compounds & $3,348,924.27$ & 0.8 & 0.07 \\
\hline Total & $431,239,408.59$ & 100 & \\
\hline
\end{tabular}

\# The total revenue for Sarawak was RM 4,563,280,000 in 2009 (Source: FDS, 2009).

$22.8 \%$ to 254,903 ha (FDS, 2009), which is equivalent to $2.07 \%$ of the total land area and $3.25 \%$ of the total forested area in Sarawak (Figure 2). Non-native species such as acacia (Acacia mangium) and eucalyptus (Eucalyptus

spp.) were mostly planted, which accounted for $75.46 \%$ and $6.72 \%$ respectively of the total area of forest plantations, while native species such as kelampayan (Neolamarkia cadamba) and albizia (Paraserianthes falcataria) representing only $6.84 \%$ and $8.87 \%$ respectively. Up to October 2010 , the total gross area licensed out for forest plantation was 2.8 Mha (Mohd Bohari, 2010). Acacia is highly preferred because of its outstanding growth performance with mean growth annual increment of $28 \mathrm{~m}^{3} \mathrm{ha}^{-1}$ and are harvestable after seven years (Appanah \& Abdul Razak, 1998), shorter than the 25-year cycle in natural forests. The expansion of forest plantations is highly encouraged and Sarawak expects to reach the target of planted area of 1 Mha by 2020 (Borneo Post, 2011a), similar to an average increment of $13.2 \% \mathrm{yr}^{-1}$. 


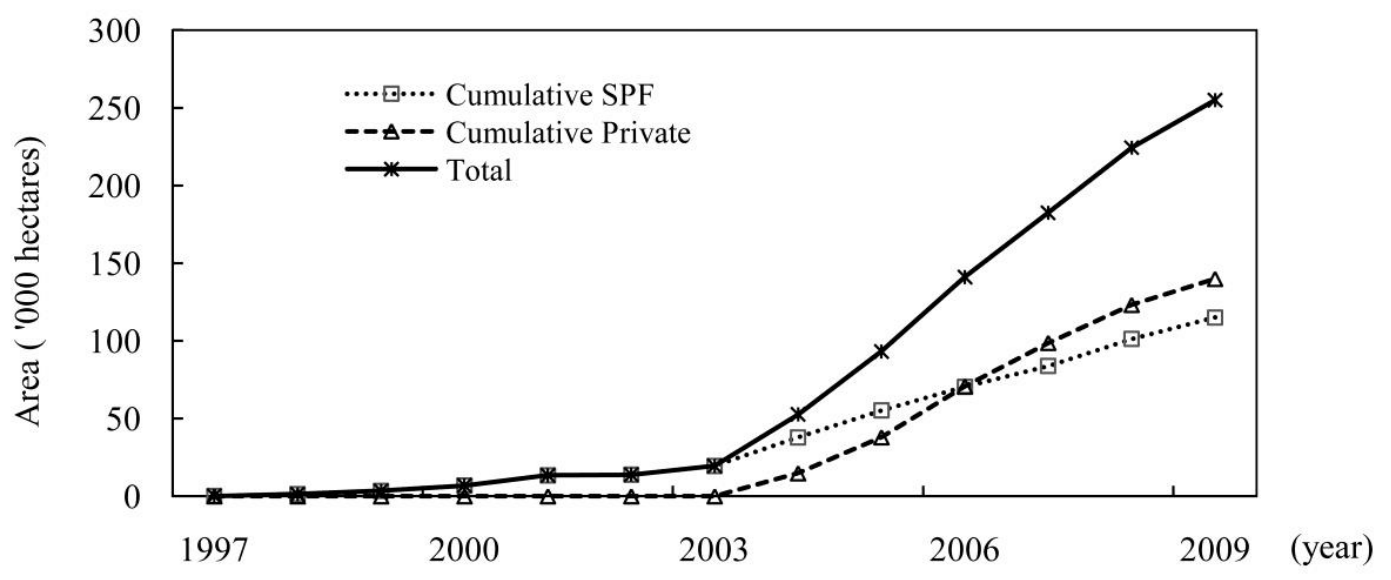

Figure 2. Cumulative area of commercial planted forests in the Sarawak.

\section{Coverage and distribution of protected areas}

On the other hand, the coverage of protected areas in Sarawak remains very low. To date, there are 23 national parks, five nature reserves and four wildlife sanctuaries, with an accumulative area of $521,562.5 \mathrm{ha}$, or $4.23 \%$ of the total land area or $6.64 \%$ of the total forested land (Table 3 ). The existing protected areas are not well connected and are located far apart, many of which are isolated. They are clustered into two main regions i.e. the southwestern and northern regions of Sarawak (Figure 3).

Table 3. Land classification showing the main categories of forested areas in Sarawak, and total coverage of totally protected and protected areas.

\begin{tabular}{lccc}
\hline Land classification & Size (ha) & $\begin{array}{c}\text { Percentage of } \\
\text { cover in Sarawak } \\
(\%)\end{array}$ & $\begin{array}{c}\text { Percentage of cover } \\
\text { over forested areas in } \\
\text { Sarawak (\%) }\end{array}$ \\
\hline Total land area & $12,315,600$ & 100 & \\
Other lands & $4,462,800$ & 36.24 & 100 \\
Forested area & $7,852,800$ & 63.76 & 35.97 \\
$\quad \begin{array}{l}\text { Forest Classification } \\
\quad \text { State land }\end{array}$ & $2,824,200$ & 22.93 & 57.39 \\
$\quad$ & & & \\
$\quad \begin{array}{l}\text { Permanent Forest Estates (Forest } \\
\text { Reserves, Communal Forests, }\end{array}$ & $4,507,038$ & 36.60 & 4.19 \\
$\quad \begin{array}{l}\text { Protected Forests)\# } \\
\text { Potally Protected Areas* (National }\end{array}$ & 329,327 & 2.67 & 2.45 \\
$\begin{array}{l}\text { Protected Areas* (Wildlife } \\
\text { Sanctuary) }\end{array}$ & 192,235 & 1.56 & \\
\hline
\end{tabular}

Source: (DOS, 2011); \# revised figure after deducting updated figure of *, based on subjective assumption by the authors and acknowledging further clarification needed, that * are gazetted from PFE. 


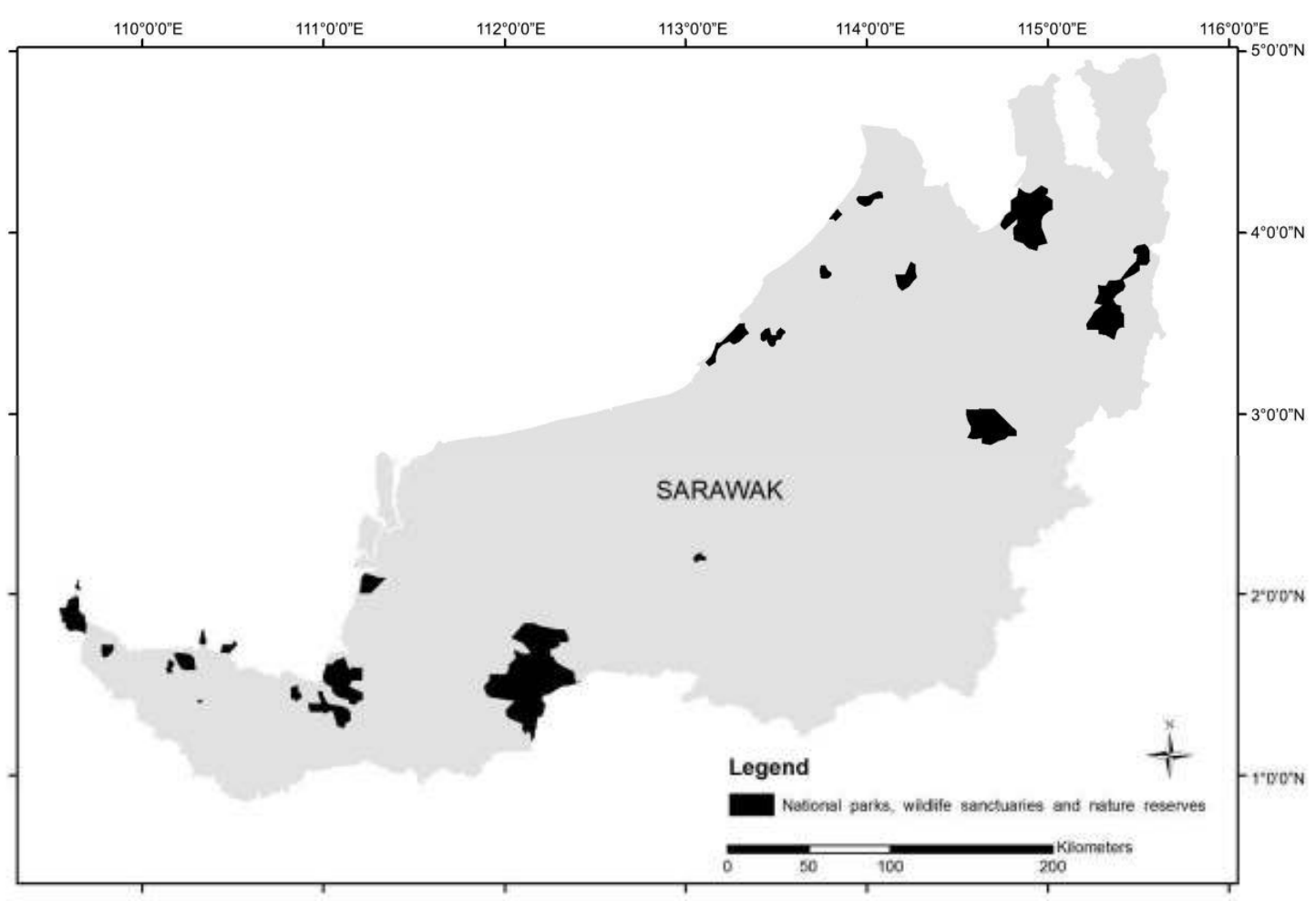

Figure 3. Distribution of protected areas (national parks, wildlife sanctuaries and nature reserves) in Sarawak.

Protected areas in Sarawak increased at an average rate of $4.9 \% \mathrm{yr}^{-1}$ from 2002 to 2011 , much lower that the rate of increase for oil palm planted area. The first national park gazetted was Bako in 1957, covering an area of 2,727 ha. Since then, there has been a gradual but slow increase in the area and number of protected areas. Sarawak aims to protect at least $10 \%$ of its land area (SFC, 2012), based on the target outlined in the Convention on Biological Diversity Conference of Parties Decision (CBD CoP7) (CBD, 2004). The existing figure of $4.23 \%$ is still below the status of global protected terrestrial areas, which stood at 12.2\% in 2009 (UNEP, 2009). Furthermore, the proposed coverage would still be inadequate to preserve the full range of biological diversity (ITTO, 1990). Some of the existing protected areas are far apart or are situated next to other forms of land uses, threatening their long term integrity. For instance, Similajau National Park (NP) is situated next to the expanding agriculture areas that have been developed for oil palm; and Lambir Hills NP is divided by a public road and is exposed to threats such as hunting, illegal felling of trees or land encroachment by agriculture. Ironically, the protected area network in Sarawak itself requires more protection.

Recommendations for conservation of wildlife in production forests

Forestry is an important economic activity and occupies a large area of existing forested land in Sarawak. In terms of wildlife conservation, the existing spatial network of protected areas is inadequate, coupled by the slow process in gazetting more areas for protection as compared to other land use changes. The role of wildlife conservation should not and cannot rest upon protected areas only. On the other hand, production forests that are sustainably managed can provide complementary role in wildlife conservation (Fimbel et al., 2001). Thus, in Sarawak, which shares the astounding biological richness of Borneo, the best option at this point of time for effective wildlife conservation is to influence how logging is carried out. 


\section{Encourage Sustainable Forest Management}

In all production forests in Sarawak, Sustainable Forest Management (SFM) practices should be encouraged and implemented whereby forest resources and forest lands are sustainably managed to meet social, economic, ecological, cultural and spiritual needs of present and future generations (FAO, 2012b; United Nations, 2000). The Forest Stewardship Council (FSC) and Programme for the Endorsement of Forest Certification (PEFC) are examples of forest certification schemes in the world, the latter adopted by the Malaysian Standard of Malaysian Timber Certification Scheme (MTCS). Although the state agencies have pledged to promote SFM, both in natural and planted forests (Borneo Post, 2012), indicating the government's effort to sustain the forestry industry in the long run (Borneo Post, 2011b), the progress has been slow and unconvincing, as evident from the very low number of sites currently certified under any SFM certification scheme. Certification is a voluntary process in Sarawak. Prior to 2010, there were two sites i.e Selaan-Linau FMU and Anap-Muput FMU, which had undergone certification activities under the old Malaysian standards certification scheme. Anap-Muput FMU has since 2012 pursued the newly revised MTCS and was successfully certified under the Malaysian Criteria and Indicators (Natural Forest) in 2013.

The onset of expansion of forest plantations in Sarawak was due to the declining stocks of timber in natural forests. Other factor is attributed to the higher production yield (Vanclay, 1996), largely because of the homogeneity of tree species that can be clear felled upon maturity, generating a constant supply of timber. However, one may argue that it is the poor management of natural forests i.e. lack of SFM implementation that has resulted in over-exploitation and decreasing timber stocks. Whether increasing the area of forest plantations presents a solution to the decreasing naturally forested area and timber production is not proven as the original land use before conversion, in many instances, is not known. Clearing natural forest prior to replanting with non-native species would actually compromise the quality of forest cover. Instead, forest plantations should be encouraged in degraded forest types, so that forest cover can be restored upon the maturity of these planted trees.

In terms of wildlife conservation, all is not lost as large scale forest plantations may still hold some hope; at least the impact is not as severe as compared to full conversion to monoagricultural plantations. Diversity may be partially preserved in a managed forest environment but totally lost if converted (ITTO, 1990). For instance, the implementation of reduced impact logging methods in tropical forests may result in biodiversity enhancement over the long term (Edwards et al., 2012). Therefore, it is crucial to engage in wildlife conservation activities in line with SFM inside production forests, of which it is heartening to note the commitment of FDS to work together with timber licensees in this aspect (Tisen \& Bennett, 2002). After all, most of the existing protected areas are not large enough and are situated far apart (Bennett \& Shebli, 1999), hence forests in between protected areas, largely under logging operations in natural or planted forest types, may connect protected habitat for wildlife and function as wildlife corridors. One commendable achievement is the implementation of the Master Plan for Wildlife (WCS, 1996), which is the only comprehensive, cross-sectoral master plan for wildlife (Gumal et al., 2007), but a full revision is timely, considering the extent of land use changes that have happened since this document was prepared. Undeniably, more forests have become part of intensely managed landscape mosaics that still contain substantial biodiversity (Zagt et al., 2010). Apart from production forests, the revision should also incorporate the roles of agricultural land, which is increasing and replacing forested areas at a very fast rate. Furthermore, the slack in implementing SFM at the policy level is a stumbling block in addressing the need for a more prudent management of the production forests in Sarawak.

\section{Collaborative research in production forests}

The conditions of many remaining forests are at the perils of impending land use and changes largely due to the slow pace in gazetting more protected areas. Larger protected areas are also needed to support wide ranging species 
(Mohd-Azlan \& Lawes, 2011). Furthermore, existing protected areas are isolated habitat islands, and may not be favourable for some wide ranging species such as the bearded pig (Sus barbatus), which has been reported to migrate over a range of 1 Mha (Caldecott \& Caldecott, 1985) or flying foxes (Pteropus vampyrus), with a diurnal home-range of 1,120 ha (Gumal, 2004). The distribution of production forests surrounding protected areas can thus become equally important for the conservation of wildlife. This entails working together with timber companies in managing their habitat and wildlife species that occur within the concession areas by taking a holistic landscape management approach. The documentation of the Bornean endemic bay cat (Catopuma badia) (Hon, 2011) and Hose's civet (Diplogale hosei) (Mathai et al., 2010), both inside production forests showed that the approach to engage with production forests in wildlife conservation is a workable partnership. As Meijaard \& Sheil (2008) noted, working with production forests currently offers the only realistic way to maintain large scale forest landscapes in Borneo. Production forests should be integrated with protected areas as one large unit in order to maximize forest connectivity in order to create a network of pristine forests intertwined and connected by sub-optimal yet relevant habitat in production forests environment.

\section{Create buffer zones around existing protected areas}

The state of some protected areas in Malaysia during an assessment in 1997 showed many areas to be in degraded conditions and were not effectively protected because they were isolated (MacKinnon, 1997). Much of the forests outside protected areas are being converted to other agricultural uses or licensed out for logging activities, putting more pressure on existing protected areas. Logging is not only prevalent in Sarawak, but over the entire Borneo. The lowland rainforests are degraded and being lost at an alarming rate, due to clearing and conversion for timber, agricultural and development uses (Meijaard \& Sheil, 2008). While this situation warrants greater protection in existing forests that are still intact, unfortunately, even protected areas are not spared from being destroyed or degraded, whereby the rate of forest cover loss inside protected areas is faster than outside in certain parts of Indonesian Borneo (Curran et al., 2004). Ideally, a protected area should consist of a 'core area' and surrounded by a 'buffer zone'. Beyond the buffer zone is usually a 'transition area', which is not strictly delineated and allows for development activities (WRI, IUCN, \& UNEP, 1992). A protected area without any buffer zone is subjected to land use changes surrounding it, reducing its conservation capacity and exposing it to the various threats. Logging for instance, improves access to forests that were once not accessible, which subsequently results in increased hunting activities (Bennett \& Gumal, 2011). The creation of a buffer zone may be able to reduce incidences of encroachment and illegal activities inside a protected area. In many cases, protected areas in Sarawak share boundaries with productions forests or agricultural land, and have minimal or almost no buffers between them. A buffer zone allows management strategy to be put in place to regulate and restrict land use surrounding a protected area. For instance, the width of a buffer zone can be fixed (Peres \& Terborgh, 1995) or changes based on quantitative assessment of the relationship between the buffer zone and surrounding factors (Li et al., 1999). The implementation of a buffer zone concept could effectively increase the effective size of protection areas. The effect is more pronounced for very small area and will reduce the issues associated with edge effects. Thus, co-operation with logging companies is vital, where logging intensity is reduced at buffer zones, although a total ban is preferred. The indirect impacts associated with logging such as increased hunting due to increased access, can be suppressed if construction of roads inside the buffer zone is prohibited, an easy measure that can be implemented through the regulation of harvesting plan.

\section{Maintain connectivity of wildlife habitat}

With the onset of large scale land use changes, mostly from the expansions of agriculture and forest plantations, urgent consideration is needed to formulate a policy on managing wildlife at a wider landscape scale. The government should consider implementing measures to create and maintain wildlife 
corridors and enhance habitat connectivity. For agriculture and forest plantations, a viable option is to set aside corridors for wildlife by not clearing existing forest during the initial land preparation stage. Older plantations should consider creating new wildlife corridors through replanting exercise or restoring damaged buffers, especially along rivers. Wildlife corridors inside older plantations can be created by delineating and leaving behind mature trees from being harvested, or by limiting any further access to a particular area to allow succession to natural forest to occur. Alternatively, restoration planting of indigenous species, interspersed with the mature non-native trees, can be introduced. Staggered harvesting instead of clear cutting should be applied, where certain portions of the area are left unlogged over a specific amount of time, preferably between one to two years, to allow for wildlife within to move out of the cutting zone. These unlogged areas act as temporary corridors which then connect to permanent wildlife corridors or conservation area.

As of now, many areas of forest plantations are near maturity, with some ready to be harvested. Within these plantations, a diverse assemblage of wildlife communities has also also been recorded (Giman et al., 2007), suggesting that forest plantations can support substantial populations of wildlife, although the communities do not resemble those of natural forests or its original state. Nevertheless, forest plantations have roles in conservation of wildlife. Therefore, we need to ensure that there are connectivity of wildlife habitat between forest plantations and the adjacent natural forests and protected areas.

\section{CONCLUSION}

Logging and agriculture are two of the major land use types in Sarawak. Land use changes are happening at very fast pace. Sarawak's spatial network of production forests, which accounts for majority of the forested land area, play important and complementary roles in biodiversity conservation. Therefore, policies inside these production forests must include conservation and management prescriptions for wildlife. Operations in tandem with criteria for forest certification ought to be made compulsory, with strong governmental support and endorsement for companies engaging in SFM and certification processes. In production forests, the mandatory requirement for a certification scheme would partly address the issue pertaining to the conservation of wildlife and its habitat, but relying on this alone is grossly inadequate. The timber market is driven by environmentally conscious consumers who demand timber that is procured legally from sound forestry practices that reduces destruction to the environment and wildlife. In view of this, more research is encouraged and should be carried out inside production forests so as to affect how SFM can be effectively implemented in Sarawak.

\section{Acknowledgements}

This project is supported by the Environmental Management Leader Programme \& Graduate School of Global Environmental Studies, Kyoto University and is part of the Planted Forest in Equatorial Southeast Asia: Humannature Interactions in High Biomass Society Project, which is funded by the Grant-in-Aid for Scientific Research(S) by the Japan Society for the Promotion of Science. The authors would like to thank John Mathai and two anonymous reviewers for their comments, which helped improve the paper.

\section{REFERENCES}

Achard, F., Eva, H.D., Stibig, H.J, Mayaux, P., Gallego, J., Richard, T., \& Malingreau, J.P. (2002). Determination of deforestationrates of the world's humid tropical forests. Science, 297: 999-1002.

Aiken, S. \& Leigh, C. (1992). Vanishing Rain Forests: The Ecological Transition in Malaysia. New York: Oxford Uni. Press.

Appanah, S. \& Abdul Razak, M.A. (1998). Planting high quality indegenous species in Sarawak. Planted Forest in Sarawak - An International Conference 1998. Forest Dept. Sarawak.

Ashton, P. (1982). Dipterocarpaceae. Flora Malesiana Series, 1(9): 237-552. 
Ashton, P. (1995). Biogeography and Ecology. In Soepadmo, E. \& Wong, K.M. (Eds.), Tree flora of Sabah and Sarawak. Forest Research Institute Malaysia, Sabah Forestry Dept. \& Sarawak Forestry Dept. Pp XLIII-LI.

Ashton, P. (2004). Dipterocarpaceae. In Soepadmo, E., Saw, L.G., \& Chung, R.C.K. (Eds.), Tree Flora of Sabah and Sarawak vol.5. Forest Research Institute Malaysia, Sabah Forestry Dept. \& Sarawak Forestry Dept.

Bennett, E. \& Gumal, M. (2011). The interrelationships of commercial logging, hunting and wildlife in Sarawak, and recommendations for forest management. In Fimbel, R., Grajal, A., \& Robinson, J. (Eds.), Conserving wildlife in managed tropical forests. New York: Columbia Uni. Press.

Bennett, E. \& Shebli, Z. (1999). Sarawak's system of totally protected areas: will it protect Sarawak's biodiversity? Hornbill, 3: 38-45.

Bernama. (2012). Sarawak to discuss oil royalty review with federal government, says Taib. Bernama 20 August 2012.

Blaser, J., Sarre, A., Poore, D., \& Johnson, S. (2011). Status of Tropical Forest Management 2011. ITTO Technical Series No 38. International Tropical Timber Organization, Yokohama, Japan.

Borneo Post. (2011a). Technological changes and planted forest to meet increasing demand for timber. Borneo Post 20 September 2011.

Borneo Post. (2011b). Age does matter, Sarawak allows only trees which are at least 50 years old to be harvested. The Borneo Post 17 May 2011.

Borneo Post. (2012). ITTO happy with state's forest management. The Borneo Post 17 May 2012.

Brooks, T.M., Mittermeier, R.A., Mittermeier, C.G., daFonseca, G.A.B., Rylands, A.B., Konstant, W.R., Flick, P., Pilgrim, J., Oldfield, S., Magin, G., \& Hiltin-Taylor, C. (2002). Habitat loss and extinction in the hotspots of biodiversity. Conservation
Biology, 16: 909-923.

Caldecott, J. \& Caldecott, S. (1985). A horde of pork. New Scientist, 15: 32-35.

CBD. (2004). Convention on Biological Diversity. CoP 7 decision VII/30. Strategic plan: future evaluation of progress. http://www.cbd.int/decisions/cop/?m=cop07. Downloaded on 3. 9. 2012.

Corlett, R. \& Primack, R. (2008). Tropical Rainforest Conservation: A Global Perspective. In Carson, W. \& Schnitzer, S. (Eds.), Tropical Forest Community Ecology. West Sussex, UK: Blackwell Publishing. Pp 442-457.

Curran, L.M., Trigg, S.N., McDonald, A.K., Astiani, D., Hardiono, Y.M., Siregar, P., Caniago, I., \& Kasischke, E. (2004). Lowland forest loss in protected areas of Indonesian Borneo. Science, 303: 10001003.

DOA (Department of Agriculture). (2011). Sarawak Agriculture Statistics 2010: http://www.doa.sarawak.gov.my/modules/ web/page.php?id=504. Downloaded on 28 . 8. 2012.

DOS (Department of Statistic). (2010). Annual Rubber Statistic Malaysia 2010. Dept. of Statistic Malaysia.

DOS (Department of Statistics). (2011). Yearbook of Statistic Sarawak. Dept. of Statistic Malaysia Sarawak.

Edwards, D.P., Woodcock, P., Edwards, F.A., Larsen, T.H., Hsu, W.W., Benedick, S., \& Wilcove, D.S. (2012). Reduced-impact logging and biodiversity conservation: a case study from Borneo. Ecological Applications, 22(2): 561-571.

FAO (Food and Agriculture Organization). (2004). Global Forest Resources. Assessment update 2005: Specification of national reporting tables for FRA 2005. Forest Resources Assessment Programme Working Paper 81 Rome 2004.

FAO (Food and Agriculture Organiszation). (2011). Southeast Asian Forests and Forestry to 2020: Subregional Report of the Second Asia-Pacific Forestry Sector Outlook Study. Food and Agricultural Organization of the United Nations. 
FAO (Food and Agriculture Organiszation). (2012a). Food and Agriculture Commodities Production. http://faostat.fao.org/site/339/default.aspx Downloaded on 1.9. 2012.

FAO (Food and Agriculture Organiszation). (2012b). Sustainable Forest Management. http://www.fao.org/waicent/search/2_dett_ fao.asp?Lang=en\&pub_id $=137646$ Downloaded on 23.8. 2012.

FDS (Forest Department Sarawak). (2009). Sarawak Forest Department Annual Report 2009. Forest Dept. Sarawak.

Fimbel, R., Grajal, A., \& Robinson, J. (2001). Logging-Wildlife Issues in the Tropics. In Fimbel, R., Grajal, A., \& Robinson, J., (Eds.). The Cutting Edge: Conserving Wildlife in Logged Tropical Forests. New York: Columbia Uni. Press. Pp 7-10.

Ghazoul, J. \& Sheil, D. (2010). Tropical Rain Forest Ecology, Diversity, and Conservation. New York: Oxford Uni. Press.

Giman, B., Stuebing, R., \& Nyegang, M. (2007). Small carnivores in mixed-use forest in Bintulu Division, Sarawak, Malaysia. Small Carnivore Conservation, 36: 35-37.

Government of Malaysia. (1974). Petroleum Development Act 1974 Act 144. Commisioner of Law Revision, Malaysia.

Government of Malaysia. (2011). National Timber Industry Policy (NATIP).

Government of Sarawak. (1998a). National Parks and Nature Reserves Ordinance. The Government of Sarawak.

Government of Sarawak. (1998b). Wild Life Protection Ordinance. The Government of Sarawak.

Government of Sarawak. (2001). The Forests (Amendment) Ordinance 2001. The Sarawak Government Gazette Part II Vol. LVII No. 12.

GTZ (German Technical Cooperation). (1992). Promotion of Sustainable Forest Management in Sarawak, Malaysia: Project Preparation Report. Deutsche Gesellschaft fur Technische
Zusammenarbeit, Eschborn, Germany.

Gumal, M. (2004) Diurnal home range and roosting trees of a maternity colony of Pteropus vampyrus natunae (Chiroptera: Pteropodidae) in Sedilu, Sarawak. Journal of Tropical Ecology, 20(3): 247-258.

Gumal, M., Bennett, E., Robinson, J., \& Tisen, O. (2007). A Master Plan for Wildlife in Sarawak: preparation, implementation and implications for conservation. In Sodhi, N., Acciaioli, G., Erb, M., \& Tan, A. (Eds.). Biodiversity and human livelihoods in protected areas: case studies from the Malay Archipelago. Cambridge: Cambridge Uni. Press. Pp 36-52.

Hon, J. (2011). A new record for the Borneo bay cat in central Sarawak, Malaysian Borneo. CAT news 55, Autumn: 4-6.

Ichikawa, M. (2007). Degradation and loss of forest land and land-use changes in Sarawak, East Malaysia: a study of native land use by the Iban. Ecological Research, 22: 403-413.

ITTO (International Tropical Timber Organization). (1990). Report submitted to the International Tropical Timber Council by Mission Established Pursuant to Resolution I(VI) "The Promotion of Sustainable Forest Management: A Case Study in Sarawak, Malaysia". International Tropical Timber Council.

Jomo, K., Chang, Y.T., \& Khoo, K.J. (2004). Deforesting Malaysia: The Political Economy and Social Ecology of Agricultural Expansion and Commercial Logging. London \& New York: Zed Book \& UNRISD.

Koh L.P. \& Wilcove D. (2008). Is oil palm agriculture really destroying tropical biodiversity? Conservation Letters, 1: 6064.

Langner, A., Miettinenz, J., \& Siegert, F. (2007). Land cover change 2002-2005 in Borneo and the role of fire derived from MODIS imagery. Global Change Biology, 13: 2329-2340.

Laurance, W. (2007). Have we overstated the tropical biodiversity crisis? Trends in Ecology and Evolution, 22: 65-70. 
Li, W., Wang, Z., \& Tang, H. (1999). Designing the buffer zone of a nature reserve: a case study in Yancheng Biosphere Reserve, China. Biological Conservation, 90: 159-165.

MacKinnon, J. (1997). Protected Areas Systems Review of the Indo-Malayan Realm. Canterbury: The Asian Bureau for Conservation \& The World Conservation Monitoring Center/World Bank Publication.

MacKinnon, K., Hatta, G., Halim, H., \& Mangalik (1996). The ecology of Kalimantan, Indonesian Borneo. Singpapore: Dalhousie Uni. and Periplus Eds (HK) Ltd.

Mathai, J., Hon, J., Juat, N., Peter, A., \& Gumal, M. (2010). Small carnivores in a logging concession in the Upper Baram, Sarawak, Malaysia. Small Carnivore Conservation, 42: 1-9.

Meijaard, E. \& Sheil, D. (2008). The persistence and conservation of Borneo's mammals in lowland rain forests managed for timber: observations, overviews and opportunities. Ecology Research, 23: 2134.

Meijaard, E., Sheil, D., Nasi, R., Augeri, D., Rosenbaum, B., Iskandar, D., Setyawati, T., Lammertink, M., Rachmatika, I., Wong, A., Soehartono, T., Stanley, S., \& O'Brien, T. (2005). Life after logging: Reconciling wildlife conservation and production forestry in Indonesia Borneo. CIFOR.

Miettinen, J., Shi, C., \& Liew, S. (2011). Deforestation rates in insular Southeast Asia between 2000 and 2010. Global Change Biology, 17: 2261-2270.

Miettinen, J., Shi, C., Tan, W., \& Liew, S. (2012). 2010 land cover map of insular Southeast Asia in $250 \mathrm{~m}$ spatial resolution. Remote Sensing Letters, 3: 11-20.

Mittermeier, R.A., Gill, P.R., Hoffman, M., Pilgrim, J., Brooks, T., Mittermeier, C.G., Lamoreux, J., \& da Fonseca, G.A.B. (2005). Hotspots revisited: earth's biologically richest and most endangered terresterial ecoregions. Washington: Conservation International.
Mittermeier, R.A., Turner, W.R., Larsen, F.W., Brooks, T.M., \& Gascon C. (2011). Global biodiversity conservation: the critical role of hotspots. In Zachos, F.E. \& Habel, J.C. (Eds.), Biodiversity Hotspots: Distribution and Protection of Conservation Priority Areas. Berlin Heidelberg: SpringerVerlag, 2011. Pp 3-22.

MOA (Ministry of Agriculture). (1998). Third National Agricultural Policy, 1988-2010. Ministry of Agriculture, Malaysia.

Mohd-Azlan, J. \& Lawes, M.J. (2011) The efficacy of protected areas and future challenges for wildlife conservation in Sarawak. In Mokhtar, M. \& Abdul Halim, J.C. (Eds.), RIMBA2: Regional Sustainable Development in Malaysia and Australia. Bangi: Lestari. Pp 136-146.

Mohd Bohari, A. (2010). Natural forest restoration - Sarawak perspective. A paper presented at the Workshop on Natural Forest Management: Best Practices in Forest Restoration, Kota Kinabalu, Sabah. 10 November 2010. Sabah Forestry Dept.

MPOB (Malaysian Palm Oil Board). (2012). Economics and Industry Development Division.http://bepi.mpob.gov.my/index.ph $\mathrm{p} /$ statistics/area.html Downloaded on 1.9. 2012.

Myers, N. (1988). Threatened biotas: "Hotspots" in tropical forests. The Environmentalist, 8(3): 187-208.

Myers, N., Mittermeier, R., Fonseca, G., \& Kent, J. (2000). Biodiversity hotspots for conservation priorities. Nature, 403: 853858.

Odegaard, F. (2000). How many species of arthropods? Erwin's estimate revised. Biological Journal of the Linnean Society, 71: 583-597.

Peres, C. \& Terborgh, J. (1995). Amazonian nature reserves: analysis of the defensibility status of existing conservation units and design criteria for the future. Conservation Biology, 9: 34-46.

Prance, G. (1995). A comparison of the efficacy of higher taxa and species numbers in the assessment of biodiversity in the neotropics. In Hawkesworth, D. 
(Ed.), Biodiversity: Measurement and Estimation. London: Chapman \& Hall. Pp 89-99.

SFC (Sarawak Forestry Corporation). (2012). Sarawak National Parks: Biodiversity Conservation.http://www.sarawakforestry. $\mathrm{com} / \mathrm{htm} / \mathrm{snp}-\mathrm{bc} . \mathrm{html}$. Downloaded on 3.9. 2012.

Sodhi, N. \& Brook, B. (2006). Southeast Asian biodiversity in crisis. Cambridge: Cambridge Uni. Press.

Soepadmo, E. \& Wong, K.M. (1995). Tree flora of Sabah and Sarawak. Forest Research Institute Malaysia, Sabah Forestry Dept. \& Sarawak Forestry Dept.

STA (Sarawak Timber Association). (2012). MARIA (Multimedia and Research Information Assistant), Sarawak Timber Association.

Tisen, O. \& Bennett, E. (2002). Wildlife conservation as part of holistic planning for sustainable forest management. The Malaysian Forester, 65(2): 59-65.

Tsuyuki, S., Goh, M., Teo, S., Kamlun, K., \& Phua, M. (2011). Monitoring deforestation in Sarawak, Malaysia using multitemporal Landsat data. Kanto Forest Research Journal, 62: 87-90.

UNEP (United Nations Environment Programme). (2009). Progress Towards the Convention on Bilogical Diversity's 2010 and 2012 Targets for protected Area Coverage. UNEP \& WCMC.

United Nations. (2000).

A/CONF.151/26(Vol.III) Forest Principles. http://www.un.org/documents/ga/conf151/ aconf15126-3annex3.htm. Downloaded on 28.8.2012.

Vanclay, J.K. (1996). Estimating sustainable timber production from tropical forests. CIFOR Working Paper No.11: Estimating AAC in the Tropics.
WCS (Wildlife Conservation Society). (1996). Master Plan For Wildlife in Sarawak. Wildlife Conservation Society, Malaysia \& Sarawak Forestry Dept.

Whitmore, T. (1988). Forest types and forest zonation. In Earl of Cranbrook (Ed.), Malaysia. Oxford: Pergamon Press. Pp 2030.

Wikramanayake, E., Dinerstein, E., Loucks, C., Olson, D., Morrison, J., Lamoreux, J., McKnight, M., \& Hedao, P. (2001). Terrestrial ecoregions of the Indo-Pacific: a Conservation assessment. Washington, DC: Island Press.

Wilcove, D. \& Koh, L.P. (2010). Addressing the threats to biodiversity from oil palm agriculture. Biodiversity and Conservation, 19(4): 999-1007.

Wong, J. (1992). Hill Logging in Sarawak. Kuching, Sarawak, Malaysia.

Woodruff, D. (2010). Biogeography and conservation in Southeast Asia: how 2.7 million years of repeated environmental fluctuations affect today's patterns and the future of remaining refugia-phase biodiversity. Biodiversity and Conservation, 19: 919-941.

WRI, IUCN, \& UNEP (World Resource Institute, International Union for Conservation of Nature \& United Nations Environment Programme). (1992). Global biodiversity strategy: guidelines for actions to save, study, and use Earth's biotic wealth sustainably and equitably. World Resource Institute, The World Conservation Union \& United Nations Environment Program.

Zagt, R., Sheil, D., \& Putz, F. (2010). Biodiversity conservation in certified forests: an overview. ETFRN News, 51: vix. 